\title{
Struktur Naratif Cerita Rakyat Tapah Malenggang Kabupaten Batanghari, Provinsi Jambi
}

\author{
Irma Suryani*, Dwi Rahariyoso, Nurfitri Susanti \\ Sastra Indonesia, FKIP, Universitas Jambi \\ *Correspondence email: irmasuryani@unja.ac.id, jaketlusuh@gmail.com
}

\begin{abstract}
Abstrak. Penelitian ini mendeskripsikan struktur naratif cerita rakyat Tapah Malenggang berdasarkan transkripsi yang dilakukan oleh Datuk Rasyid dari tuturan Datuk Zainul dan Datuk Saharman. Cerita rakyat Tapah Malenggang, sebagai bagian dari sastra lisan masyarakat Batanghari lambat laun mengalami penyusutan, bahkan bisa dikatakan di ambang kepunahan. Melalui penelitian ini diharapkan bisa diketahui bentuk dan struktur naratif cerita rakyat Tapah Malenggang tersebut. Metode yang digunakan adalah deskriptif analisis. Hasil penelitian menunjukkan bahwa cerita Tapah Malenggang berbentuk mite (myth) dan struktur naratifnya, yaitu tokoh dan latar berfungsi secara struktural memformulasikan cerita rakyat tersebut sebagai mite/mitos.
\end{abstract}

Kata kunci: cerita rakyat; mite; struktur naratif

Abstract. This research describes the narrative structure of Tapah Malenggang folklore based on the transcription conducted by Datuk Rasyid from the utterances of Datuk Zainul and Datuk Saharman. The folklore of Tapah Malenggang, as part of the oral literature of the Batanghari people, is gradually shrinking, and it can even be said to be on the verge of extinction. Through this research, it is hoped that the form and structure of the Tapah Malenggang folklore can be known. The method used is descriptive analysis. The results showed that the Tapah Malenggang story was in the form of myths and its narrative structure, namely the characters and settings functioned structurally to formulate the folklore as myth.

Keywords: folklore; myth; narrative structure

\section{PENDAHULUAN}

Keberadaan sastra lisan sebagai bagian dari tradisi lisan di Jambi, ini memang semakin terpinggirkan perkembangan zaman. Semakin masifnya era digital dan teknologi, problem kelisanan dalam masyarakat terutama sastra lisan, sudah termediasi dan digantikan bentuk tekstual dan visual (budaya layar). Kenyataan yang muncul, persebaran sastra lisan Jambi hanya terbatas pada ingatan penuturnya dan dokumentasi (teks, arsip) dari masyarakat yang masih meyakini sastra lisan tersebut sebagai bagian dari aktivitas dan praktik kebudayaannya.

Salah satu cerita rakyat di Jambi yang cukup terkenal adalah cerita rakyat Tapah Malenggang. Cerita ini merupakan cerita yang diyakini berasal dari Kabupaten Batanghari, akan tetapi mengalami persebaran di masyarakat sepanjang wilayah aliran Sungai Batanghari. Selama ini, transmisi cerita rakyat secara lisan mengakibatkan terjadinya persebaran dan variasi cerita secara kultural, baik itu disengaja oleh penuturnya (dengan tujuan tertentu) maupun tidak disengaja oleh penuturnya. Kenyataan ini menunjukkan bahwa suatu cerita rakyat memiliki pola naratif yang berupa struktur dan juga bentuk sesuai dengan komposisi naratif di dalamnya.

Tradisi lisan dalam masyarakat sebagai laku kebudayaan pada akhirnya menghasilkan suatu bentuk karya seni lisan, yaitu sastra lisan yang memiliki pertalian erat dengan keyakinan masyarakatnya. Sastra lisan ini berupa tuturan yang memiliki aspek struktural (wujud) sebagai sebuah fakta dari kebudayaan lisan dan juga memiliki aspek makna (konsep) sebagai sebuah keyakinan yang mengikat ritus dalam aktivitas kebudayaan masyarakatnya.

Dalam masyarakat di mana tradisi lisan hidup dan berkembang, sastra lisan berkembang melalui serangkaian pesan, kisah-kisah, kesaksian (baik secara kolektif maupun individual) melalui model pewarisan lisan antargenerasi (Vansina, 1985). Perwujudan dari kesaksian tersebut secara genre bisa berupa, puisi, peribahasa, dan juga cerita rakyat atau dongeng. Selain itu, sebagai suatu karya seni lisan, sebenarnya sastra lisan merupakan sebuah fakta kejiwaan (mentifact), yang menjadi bagian dari proses kesadaran masyarakat penuturnya secara turun-temurun (Kartodirdjo,1992). Dalam kenyataan tersebut, persebaran sastra lisan menjadi tidak terbatas pada kondisi budaya atau area tertentu melainkan juga menghasilkan suatu resepsi alias penerimaan yang menghasilkan variasi-variasi lain sebagai wujud distribusinya dengan corak kemiripan atau linearitas, seperti unsur motif (Finnegan, 1992).

Sebagai sebuah kesadaran masyarakat penuturnya, kepentingan dari kajian sastra lisan adalah menemukan corak, bentuk, makna, manifestasi, hingga sistem pengetahuan dari kebudayaan lisan sebelum semuanya tersebut musnah akibat perubahan zaman dan kebudayaan. (Taum, 2011) dalam bukunya, mengatakan bahwa definisi istilah sastra lisan sendiri sebenarnya agak kontradiktif dan kompleks. Hal ini dikarenakan bahwa secara etimologis, ontologis dan epistemologis, 
kodrat hakikat serta realitas estetik dalam kerangka sastra lisan tidak bisa dengan mudah didudukkan. Dalam kenyataan tersebut, Taum dengan sangat berhati-hati memberikan simpulan terhadap sastra lisan berupa definisi kerja, yaitu sekelompok teks yang disebarkan turun-temurun secara lisan, di dalamnya terkandung sarana-sarana kesusastraan yang secara intrinsik bertalian erat dengan keyakinan dan kebudayaan suatu kelompok masyarakat (Taum, 2011).

Sastra lisan sebagai suatu objek material memiliki ciri-ciri yang bisa diidentifikasi secara struktural dari perwujudannya (Taum, 2011), yaitu

a. Berwujud teks sastra yang disebarkan secara lisan. Dalam ciri ini diperoleh kenyataan adanya unsur nilai dan cara. Unsur nilai berkaitan dengan dimensi kesastraan (estetik dan puitik). Unsur cara berkaitan dengan medium yang digunakan dalam menyebarkan tuturan tersebut.

b. Sastra lisan hadir dalam bahasa nusantara atau daerah dan masih dituturkan oleh masyarakat pemiliknya.

c. Sastra lisan memiliki ragam versi dan variasi yang cenderung berbeda-beda, penyebabnya tidak lain karena metode penyebarannya secara lisan.

d. Penyebaran sastra lisan cenderung tetap dalam jangka waktu lama, kondisi ini menjadikan sastra lisan bertahan secara tradisional.

e. Terdapat konvensi dan poetika tersendiri sebagai perwujudan estetika sastra lisan yang bisa dibedakan dari sastra tulisan.

Salah satu bagian dari sastra lisan adalah cerita rakyat. (Djamaris, 1993) memberikan klasifikasi cerita rakyat sebagai berikut,

"Cerita rakyat merupakan golongan cerita yang hidup dan berkembang secara turun-temurun dari satu generasi ke generasi berikutnya. Disebut cerita rakyat karena cerita ini hidup di kalangan rakyat dan hampir semua lapisan masyarakat mengenal cerita tersebut. Cerita rakyat biasanya disampaikan secara lisan oleh tukang cerita yang hafal alur ceritanya, itulah sebabnya cerita rakyat disebut juga sebagai sastra lisan. Cerita disampaikan oleh tukang cerita sambil duduk-duduk di suatu tempat kepada siapa saja, anakanak, dan orang dewasa."

Kutipan tersebut secara tegas menjelaskan keterkaitan antara cerita rakyat dan sastra lisan. Cerita rakyat dengan demikian sangat dekat dengan masyarakat tradisional dengan basis kelisanan yang dominan. (Taum, 2011) secara spesifik menjelaskan hakikat sastra lisan, yaitu

"Cerita rakyat (fokltale) sejenis cerita prosa yang tergolong fiksi, bisa didasarkan pada suatu kejadian nyata, bisa juga rekaan, dan tidak terlalu serius sifatnya. Dalam cerita rakyat tidak ada gambaran waktu maupun tempat tertentu. Meskipun demikian, cerita rakyat memiliki fungsi penting sebagai sarana ajaran moral."

Berdasarkan dua kutipan di atas, bisa disimpulkan bahwa cerita rakyat juga merupakan bagian dari sastra tradisional yang mana keberadaannya bisa diasumsikan sebagai perwujudan ekspresi masyarakatnya secara lisan (Mitchel, 2003).

Cerita rakyat memiliki struktur naratif yang bisa diidentifikasi secara struktural dengan memosisikan aspek-aspek intrinsik di dalamnya. Penelitian ini menggunakan konsep Propp sebagai kerangka utama analisisnya. Propp mengenalkan analisis struktur naratif dengan menunjukkan pada fungsi atau tindakan yang dilakukan oleh pelaku dalam cerita rakyat. Naratif dalam pengertian yang dimaksudkan mengarah pada urutan kausalitas kejadian atau peristiwa dalam suatu cerita (Rimmon-Kenan, 1983). Tujuan dari analisis struktural adalah memaparkan secermat mungkin dari keterhubungan elemen-elemen yang terkandung dalam suatu karya sehingga mencapai keutuhan makna (Teeuw, 1984). Analisis Propp mengarah pada gagasan Saussure yang berupa pendekatan sintagmatik. Pendekatan sintagmatik ini merupakan pendekatan yang berfokus pada struktur horisontal suatu cerita; juga bisa diasumsikan sebagai pembahasan terhadap struktur permukaan cerita (Rimmon-Kenan, 1983)

Sintagmatik mengarahkan suatu pola analisis berdasarkan urutan tempat dalam cerita Selain itu, penelitian ini juga memformulasikan hubungan antara fungsi tindakan sebagaimana yang dimaksudkan Propp dalam peristiwa dengan aspek intrinsik yang menjadi bagian dalam struktur naratif cerita rakyat Tapah Malenggang. Aspek intrinsik yang dimaksudkan dalam hal ini adalah analisis terhadap satuan peristiwa (plot), latar, dan tokoh. Tujuan dari formulasi ini yaitu untuk menemukan suatu kesesuaian bentuk cerita rakyat dengan aspek intrinsik yang menjadi formulanya. Sehingga dapat ditemukan suatu korelasi detail dari aspek-aspek cerita tersebut dengan fungsi masingmasing aspek tersebut dalam cerita rakyat.

Beberapa penelitian terdahulu tentang kajian terhadap cerita rakyat dikemukakan secara referensial untuk melihat relevansinya.

Penelitian pertama, tentang "Variasi Legenda Kamandaka Berdasarkan Transmisi Masyarakat Pendukung" yang dilakukan oleh (Widya Putri Ryolita, 2018). Penelitian tersebut memaparkan tiga variasi cerita legenda Kamandaka berdasarkan transmisi dan fungsi cerita. Variasi cerita Kamandaka, yaitu versi dari Sri Yulianingsih, juru kunci petilasan Carangandul, versi Budi Sasongko (keturunan kerajaan Pasirluhur), dan Carlan (pengurus situs purbakala Dinas Pariwisata dan Kebudayaan Banyumas). Tiga variasi tersebut menghasilkan fokus penceritaan yang berbeda-beda, terutama pada cara mengungkapkan ide-ide kepada pendengar. Kesamaan penelitian ini dengan penelitian 
Ryolita, terletak pada variabel objek formalnya, yaitu transmisi yang menghasilkan variasi cerita rakyat oleh penuturnya. Perbedaannya terletak pada metode dan capaian, penelitian ini akan menggunakan metode etnografi dengan fokus menelaah aspek variasi sesuai aspek intrinsik dan gejala (konteks) dalam masyarakat yang menyebabkan variasi cerita hadir.

Penelitian kedua, tentang "Kajian Antropologi Sastra dalam Cerita Rakyat Kabupaten Banyuwangi pada Masyarakat Osing" yang dilakukan oleh (Lutfi Irawan Rahmat, 2019). Penelitian tersebut mendeskripsi unsur antropologi, meliputi bahasa, religi, mitos, hukum, maupun adat istiadat yang terdapat dalam cerita rakyat Kabupaten Banyuwangi. Kesamaan penelitian ini dengan penelitian Rahmat terletak pada objek materialnya, hanya saja orientasi penelitian ini lebih mendalam karena melihat gejala variasi dalam persebaran cerita rakyat di suatu daerah.

Penelitian ketiga, tentang "Struktur Naratif Cerita Rakyat Jambi: Telaah berdasarkan Teori Vladimir Propp" yang dilakukan oleh (Agatha Trisari, S dan Siti Chamamah Suratno, 2001). Penelitian ini menghasilkan kajian tentang fungsi terhadap lima cerita rakyat Jambi, yaitu cerita Tapah Malenggang, cerita Malin Tembesu, cerita Raja Kolong, cerita Numang Kasia, dan cerita Putri Tanglung. Temuan yang dikemukakan dari penelitian tersebut yaitu bentuk kerangka urutan fungsi pelaku tidak tetap, berpola putar balik. Meskipun masing-masing cerita berasal dari wilayah berbeda, akan tetapi struktur naratif ceritanya relatif sama. persamaan penelitian ini dengan penelitian Trisari dan Suratno tersebut terletak pada objek material, yaitu cerita rakyat Jambi, terutama cerita Tapah Malenggang. Perbedaannya terletak pada data yang digunakan serta objek formalnya. Data dalam penelitian Trisari dan Suratno tersebut adalah data hasil inventarisasi, sementara penelitian ini akan menggunakan data inventarisasi dan juga data wawancara dari penutur (pendongeng).

Penelitian keempat, "Sistem Proyeksi CeritaCerita Rakyat Nusantara di Indonesia" yang dilakukan oleh (Adika dan Dimas, dkk, 2018). Penelitian ini menemukan bentuk kajian penanda proyeksi terhadap penulis cerita rakyat di Indonesia dengan menggunakan pendekatan linguistik, yang menghasilkan suatu proses verbal dari pada proses mental. Persilangan antara sistem level dan mode menghasilkan proyeksi jenis lokusi parataktik paling sering digunakan oleh penulis teks naratif cerita rakyat Indonesia. Penelitian tersebut menyimpulkan bahwa banyaknya proyeksi jenis lokusi parataktik karena; 1) teks naratif cenderung menghendaki banyaknya dialog antar tokoh yang disampaikan dengan mode langsung (parataktik). 2) Pilihan penggunaan proyeksi lokusi parataktik membuat cerita lebih hidup dan lebih mudah dirasakan oleh pembaca. Perbedaan penelitian ini dengan penelitian yang akan dilakukan, terletak pada kerangka paradigma dan operasionalnya. Penelitian ini fokus pada identifikasi jenis klausa melaui proyeksi penanda linguistik dalam rangka menemukan polanya, sedangkan penelitian yang akan dilakukan cenderung mengarah pada identifikasi aspek struktur naratif cerita rakyat dengan melihat kemungkinan sebarannya.

Penelitian ini secara umum bertujuan untuk mengidentifikasi dan menganalisis bentuk serta struktur naratif cerita rakyat Tapah Malenggang di Kabupaten Batanghari. Melalui identifikasi dan analisis tersebut diharapkan akan diketahui bentuk dan struktur dari cerita rakyat Tapah Malenggang yang ada di Kabupaten Batanghari, Provinsi Jambi.

\section{METODE}

Penelitian yang peneliti lakukan ini termasuk kepada jenis penelitian kualitatif. Mcmillan dan Smasher (Syamsuddin dan Damaianti, 2009) mengemukakan bahwa penelitian kualitatif adalah suatu pendekatan investigasi karena biasanya peneliti mengumpulkan data dengan cara bertatap muka langsung dan berinteraksi dengan orang-orang yang terlibat dalam penelitian. Bisa diartikan juga bahwa penelitian kualitatif adalah studi yang penekanannya berhubungan dengan aktivitasaktivitas, situasi-situasi atau bahan-bahan yang memerlukan deskripsi yang utuh tentang sesuatu.

Penelitian struktur cerita rakyat Tapah Malenggang ini merupakan penelitian folklor atau lapangan. Data penelitian dikumpulkan dengan menggunakan metode pustaka dan metode etnografis. Untuk mendapatkan data yang lebih lengkap, peneliti melakukan berbagai teknik, baik teknik langsung maupun teknik tidak langsung. Menurut (Danandjaja, 2007) bahwa pengumpulan atau penginventarisan folklor dapat dilakukan dengan dua cara, yaitu; (1) mengumpulkan semua judul karangan (buku dan artikel), yang pernah ditulis orang mengenai cerita rakyat Tapah Malenggang; dan (2) mengumpulkan bahan-bahan cerita rakyat Tapah Malenggang dari hasil wawancara. dan hasilnya kemudian langsung diarsipkan. Tujuan dari teknik ini adalah untuk melengkapi penelitian

Metode pustaka berfungsi untuk melacak sebaran secara tekstual atau cetak atas variasi cerita rakyat Tapah Malenggang, sedangkan metode etnografis digunakan untuk mendapatkan data cerita rakyat Tapah Malenggang lengkap dengan variasinya secara lisan. Kedua hasil data dari metode yang dilakukan tersebut kemudian dikomparasikan dan dianalisis untuk menemukan dan melihat variasi yang muncul dari cerita rakyat Tapah Malenggang. Selanjutnya data akan disajikan secara deskriptif analisis. Data yang dikumpulkan adalah data kualitatif yang berupa deskripsi struktur dari cerita rakyat Tapah Malenggang.

Data penelitian ini adalah struktur cerita rakyat Tapah Malenggang dalam bentuk teks, yang berupa satuan naratif (struktur intrinsik) dan akan dipilah fungsi 
masing-masing unsurnya. Identifikasi struktur atau tata naratif ini mengacu pada gagasannya Vladimir Propp untuk melihat apakah ada variasi dari cerita rakyat Tapah Malenggang. Sumber data dalam penelitian ini diperoleh melalui observasi langsung, wawancara, dan perekaman dari penutur cerita rakyat, yaitu ketua adat, ninik mamak, atau orang yang mengetahui cerita rakyat Tapah Malenggang. Penelitian ini adalah penelitian kualitatif, maka data penelitian ini berupa data teks (arsip cerita rakyat, transkripsi), rekaman (audio), serta visual (foto).

Data yang dikumpulkan akan dianalisis dengan menggunakan pendekatan naratif Vladimir Propp, yang berfokus pada menganalisis karakter cerita dan fungsi penceritaan (Taum, 2011). Selain itu, perbedaan variasi yang terjadi juga akan dikaitkan dengan latar belakang penuturnya, melalui data hasil wawancara dan juga melalui studi pustaka. Hal ini untuk mengetahui variasi penceritaan, fungsi, dan transmisi yang dilakukan oleh penutur.

Data yang terkumpul dianalisis dengan prosedur seperti berikut ini.

a) Seleksi, yaitu menyeleksi data, baik data pustaka maupun data wawancara yang memberikan informasi tentang struktur variasi cerita rakyat Tapah Malenggang. Data pustaka berupa hasil kajian, tulisan, atau arsip tentang cerita rakyat Tapah Malenggang. Data wawancara adalah hasil rekaman cerita rakyat Tapah Malenggang yang diperoleh dari narasumber.

b) Transkripsi, data wawancara tentang cerita rakyat Tapah Malenggang yang sudah direkam, ditranskripsi ke dalam bahasa tulis.

c) Penerjemahan, setelah data tentang cerita rakyat Tapah Malenggang ditranskripsi secara tertulis, selanjutnya diterjemahkan ke dalam bahasa Indonesia.

Menganalisis struktur cerita rakyat Tapah Malenggang berdasarkan format analisis naratif Vladimir Propp, yaitu menjelaskan satuan-satuan naratif yang menjadi struktur cerita.

\section{HASIL DAN PEMBAHASAN}

Seiring berjalannya waktu, proses transmisi yang terjadi termasuk persebaran secara lisan dari cerita rakyat Tapah Malenggang lambat laun mengalami penyusutan, bahkan bisa dikatakan di ambang kepunahan. Kondisi ini merupakan suatu kenyataan yang harus secara sadar disikapi, bahwa ingatan, penutur, dan pewaris, dalam proses transmisi sastra lisan (cerita rakyat) memiliki keterbatasan.

Cerita rakyat Tapah Malenggang sendiri sejauh ini sudah dituliskan dan menjadi arsip tekstual yang ada di Kabupaten Batanghari. Proses transkripsi menjadi dokumen (teks) tersebut dilakukan oleh Datuk Rasyid, ketika penutur cerita rakyat Tapah Malenggang, yaitu
Datuk Zainul dan Datuk Saharman diundang ke rumah Adat Batanghari untuk menuturkan kisah Tapah Malenggang. Tidak ada keterangan persis kapan peristiwa ini terjadi, hanya berdasarkan sumber dari Popo Sean Hardi (2018), seorang Pegiat Budaya yang juga konsen meneliti cerita Tapah Malenggang. Melalui tulisan Datuk Rasyid tersebut, transkripsi dari cerita rakyat Tapah Malenggang sudah menjadi arsip yang bisa diakses publik di Kabupaten Batanghari. Secara umum, (menurut Popo) di Kabupaten Batanghari ada beberapa penutur yang juga menyatakan diri bisa menuturkan kisah cerita rakyat Tapah Malenggang, akan tetapi belum sempat terkonfirmasi sehingga data yang selama ini tersedia tentang cerita Tapah Malenggang hanya dari hasil transkripsi Datuk Rasyid.

Sebagai salah satu warisan sastra lisan yang cukup populer di masyarakat Batanghari, cerita rakyat Tapah Malenggang merupakan sebuah proyeksi tentang bagaimana masyarakat memiliki kepercayaan terhadap salah satu jenis ikan endemik sungai Batanghari. Konstruksi berpikir tersebut secara sadar merupakan perwujudan dari pemahaman ekologis yang secara kultural diwariskan turun-temurun. Ikan tapah atau dikenal juga dengan nama Wallago merupakan salah satu ikan yang hidup alami di perairan air tawar. Jenis ikan ini bisa tumbuh besar, hingga mencapai bobot 80 kilogram di habitat yang alami dan masih terjaga. Sebagai salah satu ikan air tawar yang tergolong besar (raksasa) maka keberadaan ikan ini bagi masyarakat Batanghari menjadi sakral dan dimitoskan.

Mitos dalam tradisi merupakan sebuah sistem pranata yang diyakini oleh masyarakat adat dan berkembang turun-temurun sejak dahulu sehingga mampu menjadi pembeda atau corak antara satu kelompok masyarakat dengan kelompok lainnya. (Ratna, 2011) menyatakan bahwa mitos memiliki akibat langsung terhadap keseluruhan tingkah laku individu dan masyarakat pendukungnya. Hal tersebut terkait erat dengan cerita rakyat Tapah Malenggang, yang mana sebagain besar dari masyarakat Batanghari masih mempercayai bahwa ikan tapah yang ada di sungai Batanghari merupakan ikan keramat, yang secara magis/gaib bisa menjelma menjadi dewa (manusia). Selain itu juga muncul anggapan bahwa ikan tapah merupakan ikan penunggu Sungai Batanghari. Proyeksi inilah yang menguatkan pendapat dari Ratna di atas, bahwa secara kausalitas terdapat hubungan yang erat antara mitos dengan masyarakat pemiliknya.

\section{Bentuk Cerita Rakyat Tapah Malenggang}

Cerita rakyat Tapa Malenggang merupakan cerita rakyat yang berkembang dalam masyarakat sepanjang Sungai Batanghari. Cerita rakyat tersebut bercerita tentang tiga ikan tapah sakti yang melakukan perjalanan jauh. Hingga sekarang ikan tapah dianggap sebagai ikon penting oleh masyarakat Batanghari. Dalam kehidupan masyarakat Batanghari, ikan tapah dianggap sebagai 
ikan yang suci sebagaimana termaktub dalam cerita rakyat Tapa Malenggang bahwa ada tiga anak dewa yang menjelma menjadi ikan tapah. Beberapa masyarakat di Kabupaten Batanghari yakin bahwa ikan tapah jelmaan dewa dalam cerita rakyat Tapah Malenggang tersebut, masih hidup sampai sekarang sehingga tidak boleh sembarang ditangkap.

(Dananjaya, 1994) memberikan pendapat bahwa dari semua bentuk atau genre folklor yang banyak dijadikan kajian oleh para ahli adalah cerita prosa rakyat. Hal tersebut menunjukkan bahwa prosa rakyat sebagai sebuah karya sastra lisan lebih mudah untuk diidentifikasi secara naratif dan mampu memberikan informasi terkait dengan isi yang dikandungnya. Sesuai dengan sifatnya, prosa rakyat merupakan jenis cerita bebas (karangan) yang berkembang secara turuntemurun dalam masyarakat. (Dananjaya, 1994) juga memberikan tiga klasifikasi mendasar terhadap jenis prosa rakyat, yaitu mite (myth), legenda (legend), dan dongeng (folktale).

Berdasarkan identifikasi terhadap aspek bentuk dan jenis prosa rakyat yang dikemukakan Bascom di atas, maka cerita rakyat Tapah Malenggang dikategorikan berjenis Mite (myth). Hal tersebut dapat terlihat dari perwujudan tokoh-tokohnya yang merupakan jelmaan dewa atau makhluk setengah dewa yang memiliki kemampuan melampaui manusia biasa. Tokoh-tokoh tersebut yaitu, Mambang Di Awan yang menjelma menjadi Tapah Malenggang, Mambang Di Bulan yang menjelma menjadi Tapah Kudung, dan Mambang Sakti yang menjelma menjadi Tapah Tembago. Ayah mereka bernama Sati Menggung dan ibu mereka bernama Sicindai Laut. Ketiga bersaudara tersebut meminta izin untuk menjemput Putri Kasumo Ampai yang berada di Lubuk Sebedar Alam. Putri Kasumo Ampai adalah jodoh Tapah Malenggang (Mambang Diawan). Untuk menemui jodohnya itu, Mambang Diawan harus menyamar menjadi ikan tapah. Rintangan demi rintangan dihadapi oleh ketiga kakak beradik tersebut. Mereka harus menghadapi Ular Bide, Labi-labi Putih, Rajo Mudo, dan Ular Sawo

Dalam cerita rakyat Tapah Malenggang juga disebutkan bahwa latar waktunya adalah masa lampau, bukan masa sekarang serta berlatar tempat di dunia lain, bukan dunia yang kita kenal seperti saat sekarang ini. Sebagai misal nama tempat yang disebutkan dalam latar cerita, yaitu Alam Pintu Langit dan Lubuk Sebidar Alam. Latar tempat tersebut secara jelas sesuai dengan konsep mite yang dimaksudkan oleh Bascom sebagai ciri-cirinya. Selain itu, berdasarkan relasi antara cerita rakyat Tapah Malenggang dengan kepercayaan yang berkembang di masyarakat sepanjang sungai Batanghari, bahwa ikan tapah adalah ikan keramat yang disucikan karena dipercaya sebagai perwujudan dari tokoh Mambang Di Awan.

\section{Struktur Naratif Cerita Rakyat Tapah Malenggang}

Sebagaimana yang sudah dikemukakan sebelumnya bahwa cerita rakyat dikenal juga dengan prosa rakyat sehingga strukturnya bisa diidentifikasi melalui aspek-aspek yang menyusun cerita tersebut dari awal hingga akhir. Secara struktural unsur-unsur yang menyusun dan hadir dalam cerita rakyat (prosa rakyat) memiliki kesamaan dengan unsur-unsur yang menyusun prosa fiksi modern. Melalui pendekatan struktural, identifikasi terhadap unsur-unsur cerita akan menghasilkan suatu uraian terhadap fungsi dari masingmasing satuan unsur dalam cerita tersebut serta bagaimana maknanya. Identifikasi struktur dalam cerita rakyat Tapah Malenggang dengan demikian akan menemukan seperti apa kerangka dari cerita rakyat Tapah Malenggang.

Kerangka yang dimaksudkan adalah komposisi dari unsur-unsur yang menyusun cerita dari dalam (intrinsik). Tujuannya adalah mengidentifikasi unsur apa saja dan berapa jenis unsur yang menyusun cerita secara intrinsik untuk selanjutnya dibandingkan dengan struktur naratif cerita Tapah Malenggang versi lain sehingga diketahui perbedaan serta variasi yang terjadi dari aspek naratifnya. Secara intrinsik, unsur-unsur yang diidentifikasi meliputi tokoh, alur (plot), latar yang secara signifikan memberikan kontribusi bagi kerangka cerita.

Tokoh dalam cerita rakyat Tapah Malenggang, terdiri dari tokoh utama dan tokoh figuran (sampingan). Tokoh utama, yaitu Mambang Di Awan (Tapah Malenggang), Mambang Di Bulan (Tapah Kudung), Mambang Sakti (Tapah Tembago) dan Putri Kasumo Ampai. Sedangkan tokoh figuran, yakni Sati Menggung, Sicindau Laut, Datuk Seh Sipanjang Janggut, Dewo Sakti, Siti Muno (Ular Bide), Rajo Mudo (Manteban Besi), Mambang Direte (Labi-labi Putih), Dayang, Nenek, Ikan Seluang Bersisik Emas, Ular Sawo, Bujang Selamat, Nenek Muaro Jemanti, Ulu Balang Bakurap Besi, Datuk Panglimo Tagiling Kering, Raja Sekincir Mato, Kero (kera jelmaan Mambang Sakti).

Latar dan Peristiwa dalam cerita rakyat Tapah Malenggang juga mempengaruhi perkembangan karakter tokoh terutama tokoh utama. Latar yang ditemukan dalam struktur naratif tersebut yaitu, Alam Pintu Langit, Koto Aur Berduri, Muaro Sungai Temesu, Menteban Besi (Gemulun Uluan Sungai), Muaro Kemulun Tujuh (Muaro Sungai Bekal), Lubuk Sebidar Alam, Istana Raja Sekincir Mato, dan balik lagi ke Lubuk Sebidar Alam. Secara keseluruhan ada tujuh tempat yang menjadi latar peristiwa secara kronologis sambung-menyambung dari awal hingga akhir cerita.

Secara umum gambaran alur dalam cerita rakyat Tapah Malenggang juga sangat dipengaruhi oleh latar di mana cerita berkembang dan terjadi. Melalui pertautan dengan latar sebagaimana yang sudah dikemukakan dalam bahasan sebelumnya, maka akan terlihat bahwa cerita rakyat Tapah Malenggang memiliki alur kejadian 
yang berjalan linear atau lurus. Secara sederhana, alur berkembang dengan cara atau model awal/pengenalan $\rightarrow$ tengah/puncak $\rightarrow$ akhir/penutup. Tiga fase ini sebenarnya adalah pola yang konvensional sebagaimana berlaku dalam prosa rakyat.

\section{Pembahasan}

Berdasarkan hasil penelitian di atas, maka akan dipaparkan analisis unsur intrinsik dari masing-masing aspek yang ditemukan dalam struktur cerita rakyat Tapah Malenggang di Kabupaten Batanghari. Pada paparan di atas sudah dikemukakan tentang bentuk atau jenis cerita rakyat Tapah Malenggang yang masuk ke dalam jenis mite (myth). Bentuk mite sebagaimana yang dimaksudkan mengarah pada indikasi ciri-ciri tokoh yang melampaui manusia (setengah dewa dengan kesaktian yang dimiliki bisa mengubah wujud), latar dan peristiwa (di masa lampau dan ditandai dengan peristiwa-peristiwa yang tidak masuk akal, ajaib, magis, luar biasa dan sejenisnya) yang dominan hadir dalam cerita rakyat Tapah Malenggang sehingga melalui aspek naratif tersebut cerita ini bisa dikategorikan. Selanjutnya akan diuraikan struktur naratif berdasarkan aspek-aspek yang diidentifikasi dalam cerita dan kaitannya dengan jenis atau bentuk cerita yang berupa mite.

\section{Struktur Naratif}

a. Tokoh Utama dan Tokoh Figuran (Pinggiran)

Dalam cerita rakyat Tapah Malenggang tokoh utama yang menggerakkan cerita adalah Mambang Di Awan (Tapah Malenggang), Mambang Di Bulan (Tapah Kudung), Mambang Sakti (Tapah Tembago) dan Putri Kasumo Ampai. Secara naratif, tokoh sentral yang paling banyak diceritakan dan dimunculkan adalah Mambang Di Awan dan Putri Kasumo Ampai. Secara naratif, kisah berpusat pada dua tokoh tersebut terutama pada bagian awal cerita dan juga penutup cerita, yang mana Mambang Di Awan dan Kasumo Ampai menjadikan awal mula cerita dan sekaligus penutup cerita sebagai sebuah hubungan kausalitas. Cerita dimulai dari peristiwa yang dialami Mambang Di Awan ketika memimpikan Putri Kasumo Ampai dan juga diakhiri oleh peristiwa yang dilakukan oleh Putri Kasumo Ampai sehingga Mambang Di Awan meninggalkan Putri Kasumo Ampai. Keterlibatan tokoh utama dalam cerita menghadirkan peristiwa demi peristiwa yang berbeda dan berkembang sampai pada bagian akhir cerita. Tokoh utama berada di tengah atau sebagai pusat penceritaan yang sambung-menyambung dengan latar dan peristiwa. Melalui kehadiran tokoh utama bisa diidentifikasi perkembangan cerita sesuai dengan latar dan juga berkaitan erat dengan alurperistiwa yang terjadi.

Tokoh figuran dalam cerita rakyat Tapah Malenggang muncul berdasarkan kronologis latar dan peristiwa yang dialami oleh tokoh utama. Dalam artian, setiap perkembangan cerita dari awal hingga akhir, tokoh-tokoh figuran datang silih berganti mendukung tokoh utama maupun merintangi perjalanan tokoh utama sepanjang cerita. Peran tokoh figuran ini bisa dikatakan sebagai pelengkap dan penguat karakter tokoh utama dan juga membuka kemungkinan dramatik cerita yang bermuara pada suspense (tegangan alur) sehingga cerita menjadi menarik dan dinamis. Perkembangan cerita melalui kehadiran setiap tokoh figuran juga memberikan semacam proyeksi kekuatan "imajinasi" dan khayalan terhadap tokoh utama jika dilihat kaitannya dengan jenis cerita mite. Kondisi ini secara naratif, tentu saja memberikan satu korelasi dan keterikatan mengapa tokoh figuran juga beberapa di antaranya bukan manusia biasa, melainkan juga makhluk setengah dewa, atau makhluk sakti yang memiliki kemampuan di atas manusia pada umumnya. Kendati dalam perjalanan ceritanya, tokoh-tokoh figuran selalu dikalahkan oleh "hero", yakni tokoh utama.

\section{b. Latar}

Latar yang ditemukan dalam struktur naratif tersebut yaitu, Alam Pintu Langit, Koto Aur Berduri, Muaro Sungai Temesu, Menteban Besi (Gemulun Uluan Sungai), Muaro Kemulun Tujuh (Muaro Sungai Bekal), Lubuk Sebidar Alam, Istana Raja Sekincir Mato, dan balik lagi ke Lubuk Sebidar Alam. Secara keseluruhan ada tujuh tempat yang menjadi latar peristiwa secara kronologis sambung-menyambung dari awal hingga akhir cerita.

\section{Alam Pintu Langit}

Latar tempat Alam Pintu Langit dalam cerita rakyat Tapah Malenggang, secara peristiwa juga menunjukkan karakteristik penghuninya yang sakti, memiliki keistimewaan, dan juga melampaui kapasitas manusia pada umumnya. Hal tersebut terlihat dari kedua orang tua Mambang Di Awan yang sudah mengetahui apa yang akan terjadi kepada anaknya. Termasuk ketika Mambang Di Awan menceritakan mimpi dan niatnya untuk mencari Putri Kasumo Ampai. Sati Menggung dan Sicindai Laut (ayah dan ibu Mambang Di Awan) bahkan memberikan petunjuk kepada Mambang Di Awan, perihal rintangan dan bahaya apa saja yang akan dihadapinya untuk sampai ke Lubuk Sebidar Alam. Peristiwa ini tentu di luar kemampuan manusia dan di luar nalar manusia, yang mana seorang bisa mengetahui secara detail apa yang akan terjadi dengan sangat akurat.

Dalam peristiwa di latar awal ini (Alam Pintu Langit), Sati Menggung menyarankan agar Mambang Di Awan mengajak dua saudaranya, yaitu Mambang Di Bulan dan Mambang Sakti untuk menemaninya. Mereka kemudian turun ke dunia dan menjelma (nyurup) menjadi ikan tapah. Mambang Di Awan menjadi Tapah Malenggang, Mambang Di Bulan menjadi Tapah Kudung, dan Mambang Sakti menjadi Tapah Tembago. Peristiwa penjelmaan wujud ini merupakan ciri dari mite 
yang melampaui keadaan dalam dunia manusia dan tidak terjangkau oleh nalar manusia. Keajaiban serta kesaktian tokoh menjadi formula yang memberikan karakteristik serta kesakralan cerita ini bagi masyarakat penganutnya.

\section{Koto Aur Berduri}

Dalam perjalanan menuju Lubuk Sebidar Alam, mereka bertiga menjelma sebagai ikan tapah dan menyusuri aliran sungai. Setelah melewati Rawang Sakti (sekarang daerah Sungai Bulian) lalu sampailah ketiga bersaudara tersebut ke Koto Aur Berduri. Mereka bertemu dengan seekor ikan seluang bersisik emas yang menanyakan hendak kemana tujuan mereka bertiga. Tapa Malenggang menyampaikan maksud tujuannya ke Lubuk Sebidar Alam. Ikan seluang tersebut mengatakan bahwa mereka salah arah, harusnya berbalik menuju mudik (melawan arus ke arah hulu), karena ini daerah Koto Aur Berduri. Ikan seluang tersebut juga berpesan kepada mereka bertiga agar berhati-hati jika hendak menuju Lubuk Sebidar Alam karena ada penunggunya. Para penunggu tersebut yaitu Ular Bide di Muaro Sungai Temsu, Manteban Besi di Gemulun Uluan Sungai, dan Labi-labi Putih di Muaro Kemulun Tujuh (Muaro Sungai Bekal) .

Dalam kehidupan nyata, tidak ditemukan ikan seluang yang bersisik emas. Representasi ikan seluang bersisik emas merupakan suatu bagian dari perngembangan formula cerita yang bertujuan memperkuat aspek keajaiban dan kesakralan dari cerita Tapah Malenggang. Sisik emas menandai bahwa ikan tersebut merupakan makhluk istimewa dan penting dalam ekologi sungai, sekaligus jenis ikan endemik yang memang sering ditemui di Sungai Batanghari. Dalam kenyataan masyarakat sepanjang Batanghari dan masyarakat Jambi umumnya, ikan seluang juga menjadi salah satu ikan favorit untuk dikonsumsi. Keberadaan nama-nama tempat sebagai latar cerita merupakan satu bentuk formula yang menegaskan karakteristik mite dalam prosa rakyat, Tapah Malenggang di Jambi.

\section{Muaro Sungai Temesu}

Muaro Sungai Temesu merupakan tempat di mana Tapah Malenggang menemui rintangan (penunggu sungai) pertama, yaitu Ular Bide sebagaimana yang diramalkan oleh ayahnya ketika mohon izin hendak turun ke dunia dan pergi ke Lubuk Sebedar Alam. Tapah Malenggang berkelahi dengan Ular Bide yang digambarkan sebesar punggur pohon Jelutung dengan mata merah menyala. Bisa dibayangkan bahwa sosok Ular Bide menakutkan dengan ukuran tubuh sebesar batang kayu Jelutung sementara tidak digambarkan secara detail seberapa besar ukuran Tapah Malenggang sebagai salah satu jenis ikan air tawar. Beberapa informasi menyebutkan bahwa ikan tapah di habitat yang masih alami bisa tumbuh hingga 80 kilogram bahkan lebih.
Perwujudan sosok Ular Bide maupun Tapah Malenggang dalam cerita tersebut memang menyimbolkan hal-hal yang melampaui kewajaran manusia, dengan tujuan memberikan rasa kagum, takjub, sakral, heroik, dan spiritual kepada para pendengarnya. Kondisi yang demikian melegitimasi mite sebagai sebuah kisah suci yang berfungsi memberikan ruang pemujaan, pengagungan atau penghargaan terhadap suatu kepercayaan turun-temurun dalam tradisi masyarakat adat.

\section{Menteban Besi (Gemulun Uluan Sungai)}

Menteban Besi bisa digambarkan sebagai alat yang berfungsi untuk jebakan atau menangkap sesuatu (dalam interpretasi bebas peneliti) dan tidak pernah ada yang bisa melepaskan diri darinya. Dalam cerita disebutkan bahwa bahwa Rajo Mudo yang memasang Manteban Besi. Tapah Malenggang menunjukkan kesaktiannya ketika masuk ke dalam Manteban Besi, ia tidak tertangkap dan menteban pun tidak rusak. Hal tersebut membuat penasaran Rajo Mudo, siapakah orang ini, jangankan seekor ikan bahkan manusia sakti sekali pun biasanya tidak akan pernah bisa lepas dari Manteban Besi. Kesaktian atau kehebatan (heroisme) tokoh menjadi formula yang turut memberikan pengaruh terhadap perkembangan cerita Tapah Malenggang, sehingga antara latar tempat dengan peristiwanya saling memengaruhi.

Peristiwa yang terjadi selanjutnya juga hampir sama dengan peristiwa pertemuan antara Tapah Malenggang dengan Ular Bide di Muara Sungai Temesu. Aspek yang membedakan adalah keduanya tidak melangsungkan pertarungan, melainkan hanya saling mengucapkan mantra.

\section{Muara Kemulun Tujuh}

Kemulun Tujuh digambarkan sebagai tempat yang dihuni oleh Mambang Di Retee atau Labi-labi Putih. Kondisi sungai ini digambarkan agak dangkal (airnya agak surut) dan beriak. Sosok Labi-labi Putih diwujudkan melintang di tengah sungai seperti batu sangat besar yang tak bergerak. Imajinasi tentang batu yang sangat besar sebagai perwujudan seekor labi-labi tentu merupakan sebuah hal yang luar biasa dan melampaui nalar. Kemulun Tujuh menjadi tempat terakhir yang harus dilalui oleh Tapah Malenggang sebelum tiba di Lubuk Sebidar Alam.

Tapah Malenggang pada akhirnya bertemu dengan Labi-labi Putih dan keduanya melakukan pertarungan yang sengit karena permintaan Tapah Malenggang untuk meneruskan perjalanan tidak dikabulkan oleh Labi-labi Putih. Dalam cerita, dikisahkan bahwa keduanya memiliki kesaktian dan sama-sama kuat sehingga pertarungan berlangsung lama (dalam cerita dikisahkan sudah berlangsung sehari semalam tanpa ada yang luka. Pada akhirnya keduanya mengeluarkan ajian dan senjata pamungkas, yaitu mantra untuk berubah wujud menjadi 
manusia. Peristiwa perubahan wujud ini menjadi menarik karena mantra yang diucapkan hampir sama, mirip dengan kedua peristiwa sebelumnya.

\section{Lubuk Sebidar Alam}

Lubuk Sebidar Alam digambarkan sebagai sebuah tempat atau negeri yang indah, arinya jernih dan tanahnya subur makmur. Putri Kasumo tinggal di Lubuk Sebidar Alam, di sebuah mahligai yang indah, mahligai tinggi tujuh tingkat. Peristiwa yang terjadi di Lubuk Sebidar Alam sebagaimana yang dialami oleh Mambang Di Awan dalam mimpinya. Ia menemui seorang Nenek dan memintanya untuk melamarkan Putri Kasumo Ampai.

Peristiwa demi peristiwa yang dialami oleh Tapah Malenggang termasuk sebagai formula yang menjelaskan bahwa Lubuk Sebidar Alam, bukan tempat biasa. Banyak prasyarat dan norma yang harus dijalani. Prasyarat, ritus, dan laku yang digambarkan tersebut merupakan satu elemen dalam epistemologi kebudayaan yang memiliki fungsi terciptanya keselarasan antara manusia, makhluk, dan semesta. Konsep harmonisasi ini menjadi kunci penting dalam memahami narasi cerita Tapah Malenggang ketika dikaitkan dengan penghargaan terhadap manifestasi dari ekologi yang didalamnya dikemas dengan narasi-narasi spiritual, sakral, dan suci. Tujuan rasionalnya adalah memelihara hubungan semua makhluk dengan ekosistemnya secara simbiosis mutualisme dalam rangka keberlangsungan alam dan kebudayaan bersamaan.

Secara keseluruhan, struktur naratif cerita berpusat di Lubuk Sebidar Alam. Posisi Lubuk Sebidar Alam yang kemudian menjelma menjadi negeri yang indah dengan istana yang megah, menjadi poros utama dalam rangka menmpertautkan fase pengisahan cerita dari awal hingga akhir. Peristiwa demi peristiwa paling banyak terjadi di Lubuk Sebidar Alam, dengan model kronologis dramatik yang dinamis. Cerita di Lubuk Sebidar Alam mencakup tiga aspek utama, yaitu pra pernikahan, pernikahan, dan pasca pernikahan antara Mambang Di Awan dengan Putri Kasumo Ampai.

\section{Istana Raja Sekincir Mato}

Istana Raja Sekincir Mato dalam struktur cerita tersebut memiliki fungsi sebagai sublatar (latar tambahan) dalam kronologis peristiwa yang terjadi secara umum. Sublatar yang dimaksudkan adalah latar yang memberikan fungsi memperkuat jalinan peristiwa secara kausalitas sehingga tokoh dan peristiwa memiliki kualitas dalam memainkan fase pembabakan. Urutan tempat dan peristiwa yang terjadi di dalam masingmasing bagian merupakan strategi naratif yang digunakan penutur dalam memainkan alur dramatiknya. Tanpa ada perpindahan latar dan kronologi perkembangan peristiwa bagi tokoh, penuturan atau pengisahan cerita rakyat Tapah Malenggang akan monoton untuk didengarkan.

\section{Lubuk/Koto Sebidar Alam}

Peristiwa akhir di Koto Sebidar Alam tersebut adalah pesan yang menjadi penutup dari cerita rakyat Tapah Malenggang. Pada bagian akhir cerita ini, latar peristiwa digambarkan dihancurkan oleh banjir/bencana atau bisa juga ditafsirkan sebagai dikembalikan seperti kondisi dulu, yang awalnya kecil dan sepi. Latar yang mengalami kondisi secara apokaliptik merupakan cerminan dari siklus yang terjadi dalam kehidupan manusia. Perulangan demi perulangan kondisi latar merepresentasikan bahwa manusia dan alam adalah sebuah kesatuan simbiosis yang harus seimbang. Sesuai karakteristiknya, perulangan kejadian yang berlangsung dalam cerita rakyat Tapah Malenggang menggunakan formula irasional, magis, ajaib, dan gaib. Secara naratif tujuannya jelas, yaitu sebagai cerita yang dilisankan, formula yang bersifat melampaui nalar (di luar kewajaran), dramatik, heroik, serta ajaib menjadikan komposisi cerita lebih menarik dan membangkitkan keyakinan pendengarnya karena sifat-sifat magis tersebut. Narasi tersebut menjadi sebuah kepercayaan turun-temurun yang disebarkan lintas generasi.

\section{SIMPULAN}

Secara umum cerita rakyat Tapah Malenggang di Kabupaten Batanghari memiliki bentuk dan jenis sebagai mite (myth). Hal ini dibuktikan dari tokoh-tokohnya yang melampaui manusia (memiliki kekuatan, kesaktian) dan juga latar peristiwanya yang berada di masa lampau yang juga bukan sekadar dunia manusia pada umumnya sehingga cerita cenderung berpusat pada hal-hal yang magis, gaib, luar biasa dan melampaui nalar manusia. Struktur naratif membuktikan bahwa cerita rakyat Tapah Malenggang yang terdiri dari tokoh dan latar cerita, memiliki karakteristik yang mengarah pada jenis atau bentuk cerita yaitu mite. Hal ini bisa dibuktikan dengan kondisi tokoh yang berwujud manusia setengah dewa, baik itu tokoh utama maupun tokoh figuran. Selain itu juga tokoh-tokoh memiliki kemampuan di luar batas kewajaran manusia, bahkan cenderung sakti dan bisa melakukan hal-hal ajaib. Formula ini menjadi salah satu indikasi yang paling dominan dalam rangka mengenali bentuk naratif cerita secara struktural.

Demikian halnya degan latar peristiwa yang dihadirkan, secara naratif menunjukkan pada lokasi geografis, nama tempat (toponimi) yang menggunakan perpaduan antara kondisi nyata dan dunia para dewa (di luar dunia manusia). Penamaan tempat yang asing, metaforis dan magis menambah kesakralan cerita sebagaimana menjadi kecenderungan dalam jenis mite. Termasuk di dalamnya adalah latar peristiwa yang terjadi di masa lampau, bukan waktu manusia masa kini. Waktu yang lampau memungkinkan cerita diformulasikan secara mistis, gaib, dengan keajaiban dan imajinasi-imajinasi di luar nalar manusia. 


\section{DAFTAR PUSTAKA}

Adika, Dimas, dkk. "Sistem Proyeksi Cerita-Cerita Rakyat Nusantara di Indonesia" dalam Jurnal Bahasa Lingua Scientia, Vol. 10, No. 1, Juni 2018

Agatha Trisari, $\mathrm{S}$ dan Siti Chamamah Soeratno. "Struktur Naratif Cerita Rakyat Jambi: Telaah Berdasarkan Teori Vladimir Propp" dalam Jurnal Sosiohumanika, 14 (3), September 2001

Danandjaja, James. (1994). Folklor Indonesia, Ilmu Gosip, Dongeng, dan Iain-lain. Jakarta: Grafiti.

Djamaris, Edwar.(1993). Nilai Budaya dalam Beberapa Karya Sastra Nusantara. Jakarta: Pusat Pembinaan dan Pengembangan Bahasa.

Finnegan, R. (1992). Oral Poetry Its Nature and the verbal arts. London: Routledge.

Hardi, Sean Popo. 2018, "Cerita Tapa Malenggang Sebagai Strategi Pelindungan Ekosistem Sungai Batanghari", Proceeding ICMI III, Faculty of Humanities, Universitas Jambi, hal 258-274.

Kartodirdjo, Sartono.1992. Pendekatan Ilmu Sosial dalam Metodologi Sejarah. Jakarta: Gramedia

Mitchell, Diana. (2003). Children's Literature an Invitation to the World. Boston: Ablongman.

Taum, Yoseph Yapi. 2011. Studi Sastra Lisan, Sejarah, Teori, Metode, dan Pendekatan Disertai Contoh Penerapannya. Yogyakarta: Penerbit Lamalera

Rahmat, Lutfi Irawan. "Kajian Antropologi Sastra dalam Cerita Rakyat Kabupaten Banyuwangi pada Masyarakat Osing" dalam jurnal Kredo Volume 3, No.1, Oktober 2019.

Ratna, Nyoman Kutha. 2011. Teori, Metode, dan Teknik Penelitian Sastra dari Strkturalisme hingga Postrukturalisme Perspektif Wacana Naratif. Yogyakarta: Pustaka Pelajar

Rimmon-Kennan, Slowmith (1983). Narrative Fiction: Contemporary Poetics. London: Methuen \& Co Ltd.

Ryolita, Widya Putri. "Variasi Legenda Kamandaka Berdasarkan Transmisi Masyarakat Pendukung" dalam jurnal Haluan Sastra Budaya, Volume 2, No. 2, Desember 2018.

Syamsudin, A.R., dan Vismaia S. Damaianti. (2009). Metode Penelitian Pendidikan Bahasa. Bandung: Sekolah Pascasarjana UPI dan PT Remaja Rosdakarya

Vansina, Jan., (1985) Oral Tradition as History. Madison: The University of Wisconsin Press. 